\title{
Didactic means in knowledge and practical skills shaping in the technical education processes
}

\author{
Karol Bednarek ${ }^{1, *}$, Artur Bugała ${ }^{1}$, Natalia Budzińska ${ }^{1}$, and Mateusz Wielogórski ${ }^{1}$ \\ ${ }^{1}$ Poznan University of Technology, Institute of Electrical Engineering and Electronics, Piotrowo 3a Street, 60-965 Poznań, Poland
}

\begin{abstract}
The article deals with the didactic and technical aspects of the information media selection and organization in educational processes in the field of operation and testing the electrical components and systems. The aim was to develop a presentation means that enable the acquisition of practical skills and understanding of the theoretical aspects of the issues under consideration. The practical part presents propositions of original stands for testing and presenting the functioning of rotational speed sensors as well as linear and angular position sensors, used in electrical and IT systems in industry and vehicles. The design, physical implementation and the possibilities of applications were described.
\end{abstract}

\section{Introduction}

Currently, with the stormy development of all technology branches and the increase of complexity of the manufactured devices and systems, the appropriate technical staff knowledge, related to their designing, manufacturing, servicing and provision of appropriate technical condition is needed. It is related to effective training of the new constructors, diagnostics or service technicians. The work presents didactic and technical aspects related to the possibilities of knowledge transferring in the field of construction and functional properties of electrical, IT and mechatronic systems commonly used in industry. The role of teaching media in shaping the level of knowledge and understanding by the recipients (students, auditors or pupils) the issues under consideration, in the form of properly organized and performed research and demonstration stands, was commented. The designed and implemented didactic stands for testing and presenting the functioning of rotational speed sensors as well as linear and angular position sensors were described.

\section{The role of presentation means in theoretical knowledge and practical skills transfer}

In educational processes in technical schools and industrial training centers, besides theoretical knowledge transfer, an extremely important element is the use of properly selected teaching aids in the form of multimedia presentations with animations, preview videos, computer simulations or physical demonstration stands related to the functioning of the presented elements and systems $[1,2]$. A very important factor in teaching is to familiarize educated people with the latest scientific research: with the applied computational methods [3-13], processes of their development, tests and measurements results and their interpretation [14-19] or simulations of systems functioning [20-24]. However, the most effective means of describing the technical issues are properly organized demonstration and research stands.

\section{Description of designed constructed test stands}

Taking into account the role that physical demonstration and research stands play in the transfer of theoretical and practical knowledge, the authors designed and built two such a objects [1].

\subsection{Rotational speed sensors test stand}

In the design assumptions, the main goal was to create a stand for the visualization of functioning and testing the pin rotational speed sensors (Fig. 1).

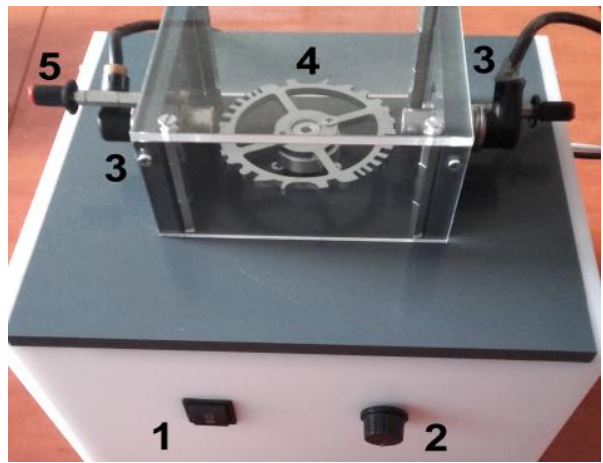

Fig. 1. A view of the prepared stand with marked components: 1 - power and rotation direction change switch, 2 - speed potentiometer, 3 - inductive rotational speed sensors, 4 - rotating ferromagnetic disk, 5 - sensor position adjustment.

Corresponding author: karol.bednarek@put.poznan.pl 
It is dedicated to didactic purposes, therefore it should allow observation of the impact of the spinning disk shape (two ferromagnetic discs with different shapes were prepared), rotational speed changes and sensor placement on the shape and parameters of the output signal.

The designed stand is functional and ergonomic, provides great versatility during testing and operational safety [1].

\subsection{Linear and angular position sensors test stand}

According to the design assumptions Hall sensors were used, and the test stand (Figure 2) allows to determine the voltage value and polarity characteristics depending on the linear or angular displacement of the moving measuring element (permanent magnet).

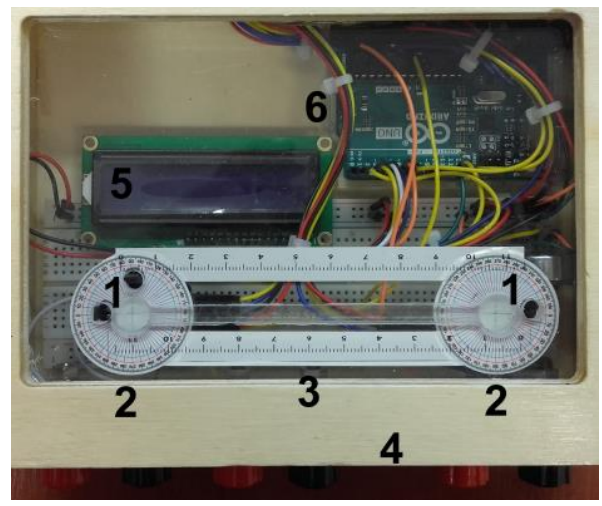

Fig. 2. A view of the prepared stand with marked components: 1 - Hall sensor, 2 - angular scale, 3 - linear scale, 4 - laboratory terminals, 5 - display, 6 - Arduino Uno with microcontroller.

Measurements are possible to be conducted for a single Hall sensor and two sensors placed perpendicularly to each other (which allows the unequivocal presentation of the angular position in the range of $360^{\circ}$ ) [1]. On the built-up stand it is possible to: conduct measurements using digital voltmeters (prepared laboratory terminals), microprocessor signal processing (using Arduino Uno with AVR Atmega 328 microcontroller) to properly adjust the Hall voltage and presentation of read data (voltage and polarity) on a display.

\section{Conclusions}

Proper selection of didactic information media (especially physical demonstration and research stands) in the theoretical technical knowledge and practical skills processes allows deep understanding of the discussed devices, activation and development of the imagination, creative thinking and action and manual skills improvement. As a consequence, it enables to achieve better results in future operations in the processes of designing, manufacturing, operating, diagnosing and servicing components and technical systems.

\section{References}

1. K. Bednarek, A. Bugała, N. Budzińska, M. Wielogórski, Poznan University of Technology Academic Journals, 100, 199-210 (2019)

2. K. Bednarek, T. Bałchanowski, Comp. Applicat. in Electrical Engineering, Poznan, 13, 197-208 (2015)

3. K. Bednarek, R. Nawrowski, A. Tomczewski, Prz. Elektrotechniczny, 84/01, 62-64 (2008)

4. A. Bugała, M. Zaborowicz, P. Boniecki, et al., Renewable \& Sustainable Energy Reviews, 81, 306312 (2018)

5. M. Filipiak, J. Jajczyk, A. Dobrzycki, ITM Web of Conferences, 19, UNSP 01034 (2018)

6. D. Głuchy, D. Kurz, G. Trzmiel, Prz. Elektrotechniczny, 90/4, 78-80 (2014)

7. J. Jajczyk, A. Dobrzycki, M. Filipiak, D. Kurz, E3S Web of Conferences, 19, 01027 (2017)

8. L. Kasprzyk, Prz. Elektrotechniczny, 83/12, 128131 (2007)

9. L. Kasprzyk, Prz. Elektrotechniczny, 88/7B, 131$133(2012)$

10. L. Kasprzyk, R. Pietracho, K. Bednarek, EKO-DOK 2018, E3S Web of Conferences, 44, 00065, 1-8 (2018)

11. L. Kasprzyk, A. Tomczewski, K. Bednarek, A. Bugała, E3S Web of Conferences, 19, 01030 (2017)

12. E. Korzeniewska, A. Szczesny, A. Krawczyk, et al., Open Physics, 16/1, 37-41 (2018)

13. D. Kusiak, Z. Piatek, T. Szczegielniak, Prz. Elektrotechniczny, 87/12B, 115-117 (2011)

14. K. Bednarek, Prz. Elektrotechniczny, 86/12, 9-12 (2010)

15. K. Bednarek, Prz. Elektrotechniczny, 87/12b, 1-4 (2011)

16. K. Bednarek, A. Bugała, D. Typańska, L. Kasprzyk, EKO-DOK 2018, E3S Web of Conferences, 44, 00010, 1-8 (2018)

17. K. Bednarek, L. Kasprzyk, Prz. Elektrotechniczny, 88/12b, 236-239 (2012)

18. Ł. Putz, D. Typańska, Prz. Elektrotechniczny, 90/3, 111-114 (2014)

19. L. Putz, M. Kurzawa, Computational Problems of Electrical Engineering (IEEE Xplore, 2016)

20. A. Bugała, K. Bednarek, ITM Web of Conferences, 19, 01021 (2018)

21. J. Jurasz, A. Piasecki, E3S Web of Conferences, 14, 01017 (2017)

22. Ł. Knypiński, L. Nowak, COMPEL, 30, 929-940 (2011)

23. M. Lebioda, J. Rymaszewski, E. Korzeniewska, Journal of Physics Conference Series, 494, 012018 (2014)

24. G. Trzmiel, M. Lopatka, D. Kurz, EKO-DOK 2018, E3S Web of Conferences, 44, 00180, 1-8 (2018) 